exhibition in 1953 and these were later transferred to the biological department of Loretto School. Although they were never given any formal lessons on the sulfject, a group of fifty schoolboys were given a surprise question in an examination paper on the habits of sea-horses. Their observations have been put together in a most stimulating article by A. S. Gillespie (School Nat. Study J., 49, 196 ; July 1954).

\section{Protection of Plants}

THE thirty-fourth report of the Quebec Society for the Protection of Plants (Pub. Dept. Agriculture, Province of Quebec, May 1954 ; n.p.) includes, among other general matters, a number of papers presented at the annual meeting and also the papers contributed to a symposium on "Viruses and the Protection of the Plant Kingdom". 'These last range widely, and include studies of infection, identification, relationships of strains, the induction of mutants, host reaction, mutual adaptation in viruses and their hosts, resistance, immunization, agents of dissermination, and other topics.

Chemical and Plastic Materials Exhibition in Paris

THE third Salon de la Chimie et des Matières Plastiques will be held at the Parc des Expositions, Porte de Versailles, Paris, during December 3-12. On each of the eight weekdays during this period a technical meeting will be held to discuss the following subjects: now vacuum techniques; perfumery and cosmetics; chromatography and ion exchange; applications of microscopy in chemistry; antifouling paints; electronic techniques in the service of chemistry; control and regulation systems in sugar refineries, and corrosion; and recent developments in plastics, and corrosion. Last year the Salon included 650 exhibitors from thirteen countries, and two hundred thousand visitors attended; this year the Salon will be even larger, and an area of just over six acres has been reserved. In all, there will be four separate but complementary exhibitions as follows : laboratory equipment (instrumentation, optical, testing, measuring, control and regulating equipment) chemical products (pure, industrial and finished products); chemical engineering (general and special plant); and plastics industry (raw materials, materials for processing, and manufactured articles). Concurrently the third session of the Chemical Engineering Conference will be held, when many of the problems encountered in the operation of modern factories will be reviewed. Further information on all these events can be obtained from the Commissariat Général, 28 rue Saint-Dominique, Paris 7e.

National Research Council of Canada : Postdoctorate Fellowships for 1954-55

THE National Research Council of Canada has awarded sixty-eight postdoctorate fellowships for the year 1954-55 for research in the Council's laboratories. The fellowships, which are worth 3,000 dollars taxfree (3,500 dollars for married men), are awarded without regard to nationality to persons less than thirty-five years of age with a Ph.D. degree of a recognized university. The distribution of the awards between the various Divisions of the National Research Council is as follows : applied biology, 10 ; applied chemistry, 9 ; pure chemistry, 25 ; physics, 17 ; and radio and electrical engineering, 1 . In addition, five fellowships will be held at the Prairie Regional Laboratory, Saskatoon, and one at Science Service of the Department of Agriculture.

\section{Pesticides Group of the Society of Chemical Industry}

THE Society of Chemical Industry is forming a new Group-the Pesticides Group-based on the former Crop Protection Panel of the Society's Agriculture Group. The present membership of the new Group is about two hundred and forty, mainly derived from the former Panel, but with the now extended terms of reference it is hoped that the Group will be widely supported by individuals and firms with an interest in pesticides, but not necessarily in the field of agriculture. The inaugural meeting and dinner of the Group will be held on October 18. Further information can be obtained from the General Secretary, Society of Chemical Industry, 56 Victoria Street, London, S.W.1.

\section{Advisory Council for Scientific and Industrial Research: New Members}

THE Lord President of the Council has appointed Dr. E. Ashby, president and vice-chancellor of The Queen's University, Belfast, Mr. S. Barratt, finance director of Messrs. Albright and Wilson, Ltd., Oldbury, Birmingham, Prof. E. A. G. Robinson, professor of economics, University of Cambridge, and Dr. C. Sykes, managing director of Messrs. Thomas Firth and John Brown, Ltd., Sheffield, to be members of the Advisory Council for Scientific and Industrial Research in succession to Prof. R. S. Edwards, Lord Halsbury, Sir Henry Hinchliffe and Mr. A. H. Wilson, who retire from the Council on September 30. Sir Hugh Beaver is to succeed Sir Ian Heilbron as chairman of the Advisory Council on October 1. The other present members of the Council who continue to serve after September 30 are : Sir Wallace Akers, J. Crawford, Prof. T. R. C. Fox, W. L. Heywood, Sir Philip Johnson, Sir Eric Rideal, Sir George Thomson and Sir Ben Lockspeiser (secretary).

\section{Announcements}

A course of twelve lectures and demonstrations on the theory of photoelasticity and the practical application of photoelastic methods to the investigation of two-dimensional stress distributions will be given in the Faculty of Engineering, University College, London, on successive Mondays (2-3 p.m.), commencing on October 11. A course of twelve lectures and demonstrations on recent developments in the photoelastic investigation of three-dimensional stress problems will similarly be given on Mondays, commencing January 31, 1955. The fee for each course is $7 \frac{1}{2}$ guineas, or 14 guineas for both (free to students of University College). Further information can be obtained from the Secretary of the College, Gower Street, London, W.C.l.

Tre Bone and Tooth Society will hold a symposium on "Vitamin D and Bone" on September 30 at the Institute of Orthopædics, 234 Great Portland Street, London, W.1, at 5 p.m. Sir Edward Mellanby will speak on "Vitamin D and Nutrition" and Dr. E. Kodicek on "Balanee Studies of Vitamin D in the Rat". "There will also be a joint contribution from Dr. J. Anderson, Dr. C. E. Dent and Dr. B. Senior on "Vitamin D and Phosphate Excretion". Further information can be obtained from the Secretary, Bone and Tooth Society, Biochemistry Department, Institute of Orthopredies, Royal National Orthopsedic Hospital, Brockley Hill, Stanmore, Middlesex. 